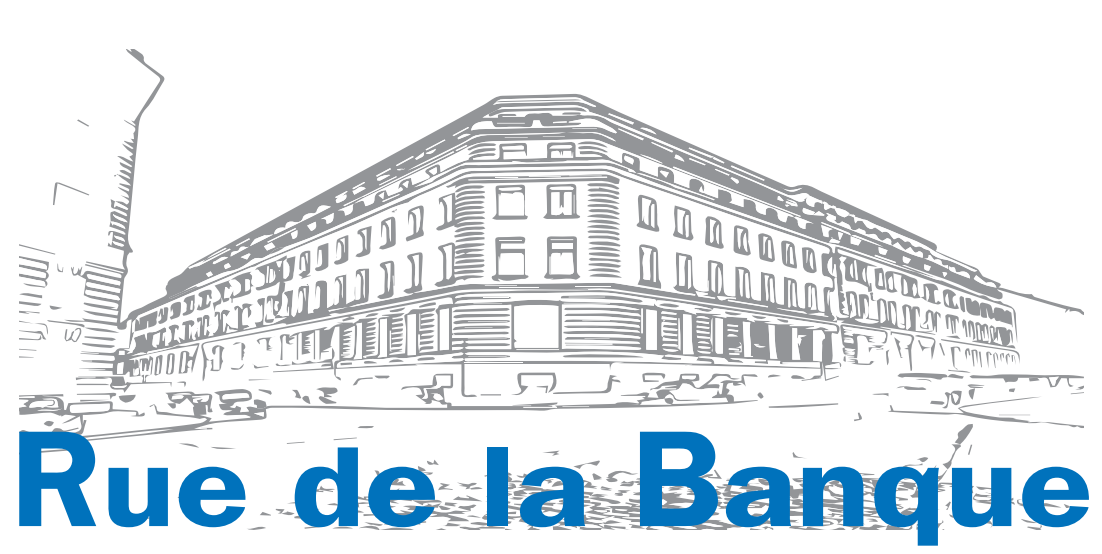

No. 7 June 2015

\title{
Productivity trends from 1890 to 2012 in advanced countries
}

\author{
Antonin BERGEAUD \\ Banque de France and École Polytechnique \\ Gilbert CETTE \\ Banque de France and Aix-Marseille School \\ of Economics (AMSE) \\ Rémy LECAT \\ Banque de France
}

This Rue de la Banque provides an overview of productivity growth and levels for 13 advanced countries during the period 1890-2012. Two productivity waves are highlighted, a big one following the second industrial revolution and a small one following the ICT revolution. The productivity convergence process has been erratic, hampered by inappropriate institutions, technology shocks, financial crises and wars; the latter led to major productivity level adjustments, downwards for countries experiencing war on their soil, and partly upwards for other countries. Productivity trend breaks are also detected following major policy changes, such as structural reforms, for instance in the Netherlands during the 1980s and in Australia, Canada and Sweden during the 1990s. The downward trend break observed as early as the mid-2000s in the United States leads to question the future contribution of the ICT revolution to productivity enhancement.
This letter presents the findings of research
carried out at the Banque de France. The views
expressed in this post are those of the authors
and do not necessarily reflect the position
of the Banque de France. Any errors or omissions
are the responsibility of the authors.
$\mathrm{P}$ roductivity is one of the main factors affecting living standards and determines the supply capacity of an economy (and hence the risk that demand exceeds this capacity and generates inflation); for these reasons it has always been given a great deal of attention in economic literature and by central banks. Two main aspects have been discussed in this literature: the factors of productivity growth and the country productivity convergence processes.

Technological progress appears to be the main engine for productivity growth, with its actual impact depending on numerous aspects. For the country at the technological frontier, i.e. the productivity leader, it depends on technological improvements and on institutions (including the quality of the State and property rights protection), these two aspects being interdependent (for a complete overview, see Aghion and Howitt, 1998, 2009, or Crafts and O'Rourke, 2013). Concerning followers (i.e. countries behind the technological frontier), the productivity growth process seems to be easier, as copying innovations is cheaper than innovating. However, copying innovation also requires appropriate institutions. As a consequence, due to inadequate institutions, the productivity convergence process of followers toward the leader(s) is often halted, if not reversed.

The aim of this study is to analyse empirically productivity levels, developments and trend breaks over a long period for a large set of 13 industrialised countries during the 1890-2012 period. Two productivity indicators are considered: labour productivity per hour worked (denoted LP) and total factor productivity (TFP). The computation of TFP is based on the usual assumptions of a Cobb-Douglas production function with constant returns to scale. We have also made the assumption of constant capital and labour service shares, each of these shares being assumed to be the same for all countries. From these two productivity indicators, waves of productivity growth are derived by smoothing and productivity trend breaks are detected using the usual statistical methodology. 
The 13 countries considered are the G7 countries (the United States, Japan, Germany, France, the United Kingdom, Italy and Canada), the other two largest countries in the euro area (Spain and the Netherlands) and four other countries that are interesting for productivity analysis because of their specificities: a high productivity level at the beginning of the period in the case of Australia, an unusual European economic integration process for Finland, a particular industrial structure in the case of Norway and the role of structural policies for Sweden. In addition, a euro area is reconstituted, which here is the aggregation of Germany, France, Italy, Spain, the Netherlands and Finland, and which corresponds to $85 \%$ of current euro area GDP.

The analysis is conducted over a long period on a large set of countries, with data ${ }^{1}$ adjusted for purchasing power parity and, as far as possible, on the basis of consistent assumptions (for example, for the capital stock, the same depreciation rate for all countries) which allow level and growth comparisons among countries for each of the two productivity indicators.

The main results are:

Over the whole 1890-2012 period, we observe two productivity growth waves in the United States, the first big one corresponding to the second technological revolution (use of electric power, the internal combustion engine, chemical production, etc.) and the second, which was smaller and shorter, to the ICT technology revolution (cf. Chart 1).

- From these two productivity growth waves with a lag, and in a less explicit way regarding the second one, with the length of this lag varying from one country to another ( cf. Chart 1): the first wave benefited the euro area, the United Kingdom and Japan after World War II, as reconstruction and technology transfers from the United States enabled a renewal of the industrial base; the second wave benefited the United Kingdom, but apparently not other European countries or Japan. Numerous studies provide differing explanations for the ICT diffusion lag observed everywhere but in the United Kingdom and the United States. This lag can be explained by differences in the average level of education of the working age population and by more stringent labour and product market regulations (Cette and Lopez, 2012).

- The productivity slowdown at the beginning of the 2000s, and mainly that in United States, leads us to question the future contribution of the ICT revolution
C1 Labour productivity waves

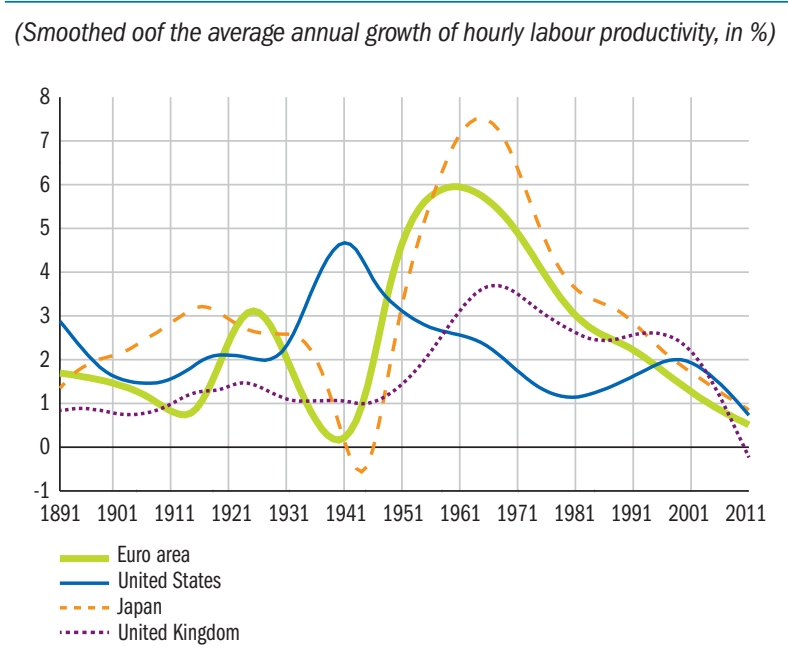

Note: Hodrick-Prescott filtering, lambda $=500$

Sources: see footnote 1; authors' calculations.

to productivity enhancement. Gordon (2012, 2013) interprets it as a huge deceleration in Moore's law. ${ }^{2}$ He stresses that the wave of productivity growth corresponding to the main ICT diffusion period is shorter and smaller than that corresponding to the previous technology shock. For him, in terms of productivity gains, this technology shock is not as large as the previous ones and US productivity growth is low after the temporary rebound that started in the 1990s. Other studies present the slowdown in the ICT productivity impact as, at least partly, the result of an increase in price-cost markups in the chip industry, or as a mismeasurement (Aizcorbe et al., 2008 or Byrne et al., 2013). Moreover, they do not rule out a second wave of productivity growth following new improvements in ICT. Other explanations for this slowdown are also plausible (for a survey, see Cette, 2014).

1 The starting database was the one built by Cette, Kocoglu and Mairesse (2009) for 4 countries, which we extended to 13 countries. The data mostly come from Maddison (1994, 2001, 2003) or Bolt et al. (2013), supplemented by specific national sources (e.g. Baffigi, 2011, for Italy or Prados, 2003, for Spain). Series for GDP and capital are given in constant national currencies as of 2005 and converted to United States dollars in purchasing power parity (PPP) using a conversion rate from the Penn World Tables.

2 Intel co-founder Gordon E. Moore observed in 1965 that the number of transistors on integrated circuits doubled every two years, a trend which has continued for half a century. 
The productivity leadership switched from Australia and the United Kingdom to the United States during the first part of the twentieth century, and then to Norway, the Netherlands and France, at least for a number of years, at the end of the twentieth century (cf. Chart 2). Regarding this last period, it would be wrong to conclude that these countries were, at that time, as efficient as the United States in terms of productivity. The working time (for all three countries) and/or the employment rate (in the case of France) were lower than in the United States. Several empirical studies find diminishing returns to hours worked and with respect to the employment rate (see Bourlès and Cette, 2005, 2007, for a survey and estimates), which means that at least part of the productivity performance of these countries was obtained from relatively low levels of hours worked or a relatively low employment rate compared to the United States. In Norway, part of the performance of labour productivity also came (and still comes) from a high level of capital intensity, linked to this country's particular industrial structure (important share of capital intensive industries such as petrol, fishing and timber).

There is no global and permanent convergence process regarding productivity levels. Divergence processes or stable gaps often appear during long sub-periods (cf. Chart 2): indeed, convergence with the productivity leader took place before World War I, in the immediate interwar period and after World War II, but it was halted by technology shocks and above all by wars, which resulted in large downward productivity adjustments in countries experiencing war on their soil and large upward adjustments in most other countries. Convergence was capped for some countries (Japan at $70 \%$ of the United States level since the 1990s) as institutional factors, among which the level of education of the working age population as well as labour, product and financial market regulation and the quality of the State, are central determinants of a country's ability of to converge.

- General productivity breaks (cf. Chart 3) appear in all countries at specific moments, such as world wars, global supply shocks (such as the oil shock of the 1970s) or global financial crises (such as those which happened at the end of the 1920s or in the late 2000s). However, these breaks can lead to upward (for the United States) or downward (for the euro area and Japan) productivity adjustments during wars, persistent stagnation (for the euro area) or a
C2 Labour productivity convergence relative to the United States' level

(Level of labour productivity per hour; US level = 100)

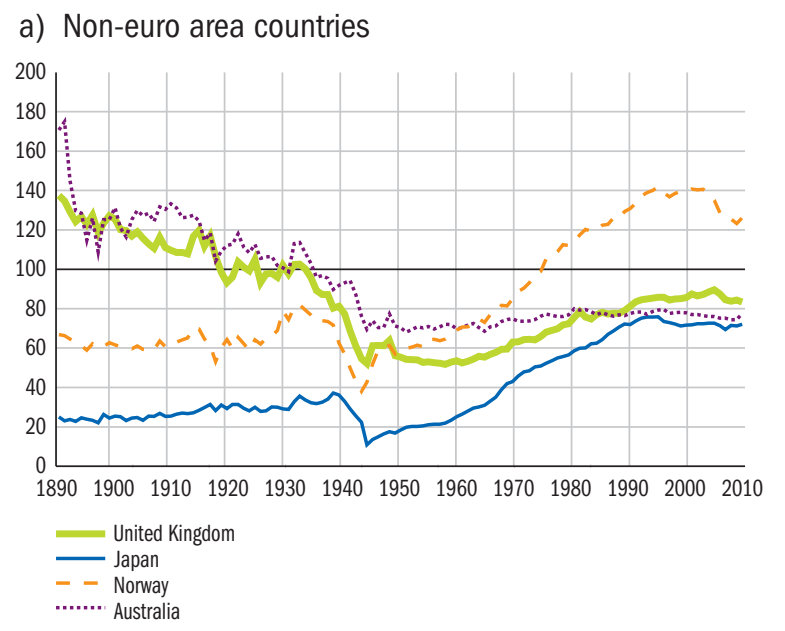

b) Euro area countries

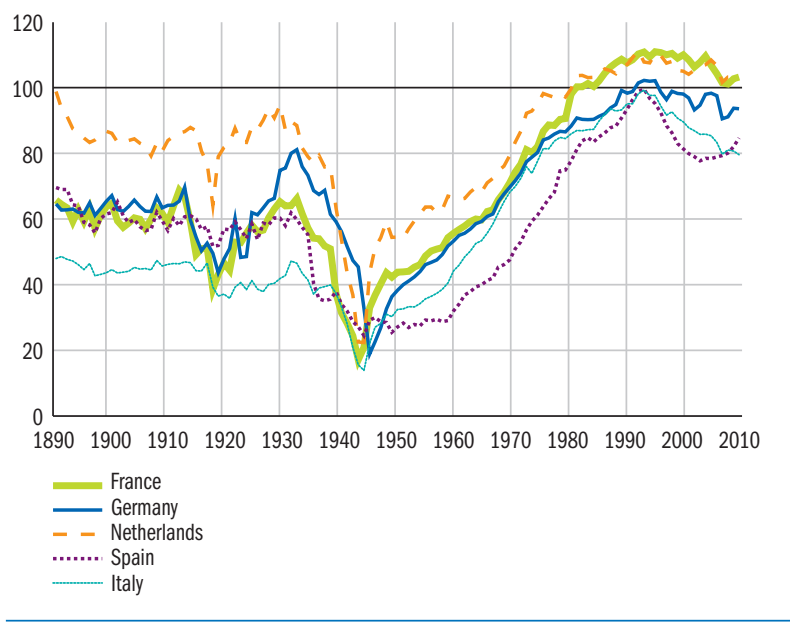

Note: data in constant national currencies as of 2005 and converted in US dollars. Sources: see footnote 1; authors' calculations.

rebound (for the United States) regarding the 1930s' Great Depression and the downward break for the 1970s oil shock was recorded between 1969 (for the United States) and 1974 (for the euro area).

Country-specific productivity breaks appear (cf. Chart 3), which can be linked to idiosyncratic shocks such as technological ones, for example the early acceleration of the ICT technology shock in the United States during the 1990s, or policy ones, for example the implementation of structural reforms in the Netherlands in the 1980s, and in Australia, Canada and Sweden in the 1990s. Concerning structural 
(Y-axis: aannual average in hourly labour productivity between two bounds; log scale)

a) United States

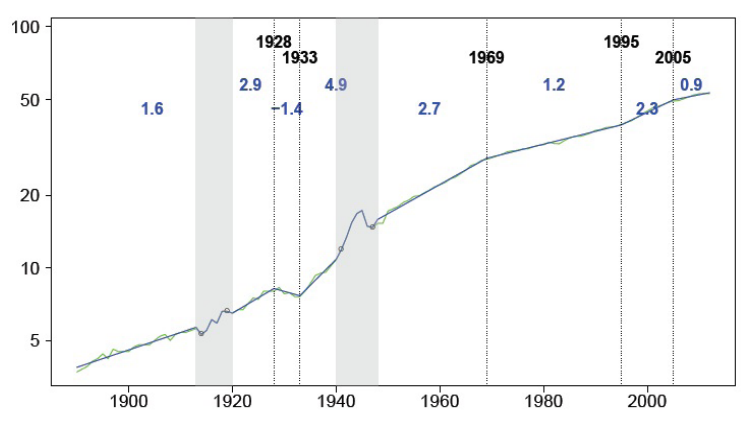

b) Euro area

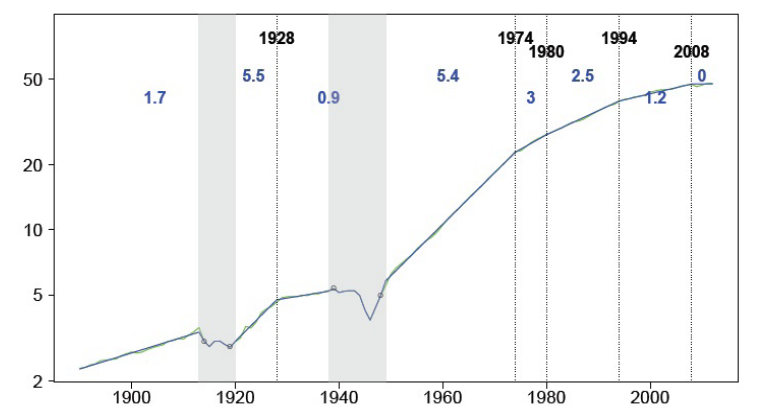

c) Japan

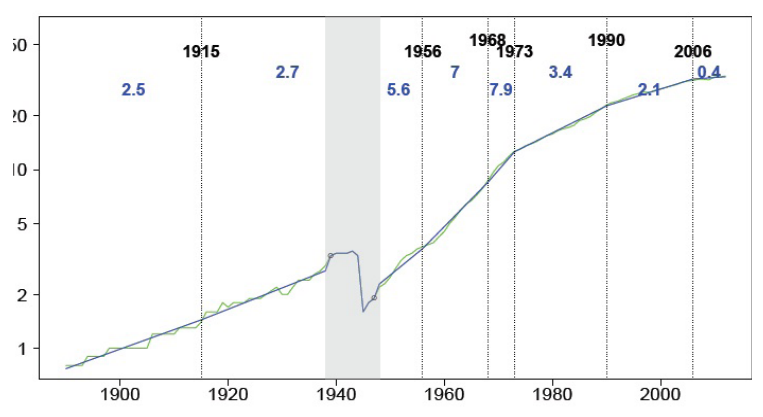

d) Sweden

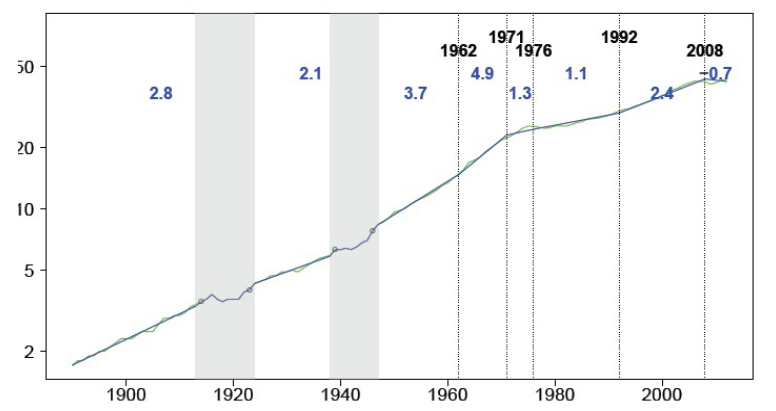

reforms, TFP growth per year increased by $1 \mathrm{pp}$ in the Netherlands and in Australia, 0.8 point in Canada and $1.5 \mathrm{pp}$ in Sweden. These numbers illustrate that the productivity impact of structural reforms can be very large, which gives a significant role to policy.
As far as comparisons are possible, these results are consistent with other analyses usually produced on one or a small number of countries and over shorter periods (see for example the survey of numerous analyses proposed by Crafts and O'Rourke, 2013). 


\section{References}

Aghion (P.) and Howitt (P.) (1998)

"Endogeneous growth theory", Cambridge, MA: MIT Press.

Aghion (P.) and Howitt (P.) (2009)

“The economics of growth", Cambridge, MA: MIT Press.

Aizcorbe (A.), Oliner (S.) and Sichel (D.) (2008)

"Shifting trends in semiconductor prices and the pace of technological progress", Business Economics, Vol. 43, No. 3, pp. 23-29.

Baffigi (A.) (2011)

"Italian national accounts, 1861-2011", Bank of Italy, Economic Research and International Relations Area, Quaderni di storia economica (Economic History Working Papers), No. 18.

Bergeaud (A.), Cette (G.) and Lecat (R.) (2014)

"Productivity trends from 1890 to 2012 in advanced countries", Banque de France Working paper, No. 475, forthcoming Review of Income and Wealth.

Download the paper

Bolt (J.) and Luiten van Zanden (J.) (2013)

"The first update of the Maddison Project; Re-estimating growth before 1820", Maddison Project Working Paper, No. 4.

Bourlès (R.) and Cette (G.) (2005)

"A comparison of structural productivity levels in the major industrialised countries", OECD Economic Studies, OECD Publishing, vol. 2005(2), pp. 75-108.

Bourlès (R.) and Cette (G.) (2007)

"Trends in 'structural' productivity levels in the major industrialized countries", Economics Letters, vol. 95(1), April, pp. 151-156.

Byrne (D.), Oliner (S.) and Sichel (D.) (2013)

"Is the information technology revolution over?", International Productivity Monitor, No. 25, Spring, pp. 20-36.

\section{Cette (G.) (2014)}

"Does ICT remain a powerful engine of growth?", AFSE Presidential Adress, Revue d'Économie Politique, 124 (4), July-August, pp. 473-492.

Cette (G.), Kocoglu (Y.) and Mairesse (J.) (2009)

"Productivity growth and levels in France, Japan, the United Kingdom and the United States in the Twenthieth Century", NBER Working Paper, No. 15577.

Cette (G.) and Lopez (J.) (2012)

"ICT demand behaviour: an international comparison", Economics of Innovation and New Technology, Taylor and Francis Journals, vol. 21(4), June, pp. 397-410.

Crafts (N.) and O'Rourke (K.) (2013)

"Twentieth century growth", Discussion Paper Series, CEPR, No. 9633, September.

Gordon (R.) (2012)

"Is U.S. economic growth over? Faltering innovation confronts the six headwinds", NBER Working Papers No. 18315.

Gordon (R.) (2013)

"US productivity growth: the slowdown has returned after a temporary revival", International Productivity Monitor, Centre for the Study of Living Standards, vol. 25, Spring, pp. 13-19.

Maddison (A.) (1994)

"Standardised estimates of fixed capital stock: a six country comparison", Groningen Growth and Development Centre, University of Groningen, GGDC Research Memorandum No. 199409.

Maddison (A.) (2001)

"The world economy, a millennial perspective", OECD publishing.

Maddison (A.) (2003)

"L'économie mondiale, statistiques historiques", OECD publishing.

Prados de la Escosura (L.) (2003)

"El progreso economico de España (1850-2000)", Fundacion BBVA, edition 1, No. 201136.

Published by

Banque de France

Managing Editor

Marc-Olivier STRAUSS-KAHN

Editor-in-Chief

Françoise DRUMETZ
Production

Press and Communication Department

June 2015

www.banque-france.fr 